\title{
Prevention and Development of Haze Should Pay Attention to the Development and Perfection of Green Finance
}

\author{
Yueying Xu \\ Fuzhou University of International Studies and Trade \\ Changle Fuzhou, China \\ 43037097@qq.com
}

\begin{abstract}
The purpose of this study was to provide financial support for prevention and control of haze dust. Haze dust has seriously affected the work and life of the Chinese people, prevention and control of it should be multi-pronged. Green finance should be one of the weapons to prevent haze dust. Based on the analysis of the present situation of green finance development in China and the experience of green finance in western developed countries, this paper concludes that the prevention and control of haze dust should promote the development of green finance: 1. Financial institutions should actively fulfill their environmental responsibilities; 2. To strengthen the system construction, construction and development of green financial incentive mechanism; 3 . To nurture and improve the social development of green financial assessment mechanism; 4. to play the guiding role of the government. The innovation of this paper lies in linking environmental governance with finance and making full use of financial capital-oriented functions for haze prevention and control.
\end{abstract}

Keywords-green finance; green finance system; environmental management; haze dust

\section{The CURRENT StATUS OF CHINA'S HAZE}

The Environmental Performance Index (2016 report), published by Yale University in the United States, stung the hearts of the Chinese people - the air quality in China was the first in the last place, second only to Bangladesh.

In order to manage the haze, the central government in 2015 to arrange special funds for air pollution control 10.6 billion Yuan to support the Beijing-Tianjin-Hebei and the surrounding areas, the Yangtze River Delta, Pearl River Delta and other key areas to carry out air pollution control. National comprehensive supply of four national standard vehicle gasolines and diesel, Beijing, Tianjin, Shanghai and other places the first supplier of five standard vehicle gasoline and diesel. Nearly three years to eliminate backward steelmaking steel production capacity of more than 9000 million tons, electrolytic aluminum more than 100 million tons, 230 million tons of cement, flat glass more than 7600 million weight boxes. Promote the clean and efficient use of coal, Beijing and Tianjin and other key areas to achieve negative growth in coal consumption. However, in front of these data, the haze is still indifferent.
China's environmental statistics began in 2007. February 2010, the national environmental pollutants statistics released, that is, by the Ministry of Environmental Protection, the National Bureau of Statistics, the Ministry of Agriculture jointly issued the "first national pollution source census bulletin." The communique shows that the total national emissions of 637203.69 billion cubic meters, the total discharge of major pollutants, sulfur dioxide for 23.2 million tons, 11.6664 million tons of soot, nitrogen oxides $17,977,000$ tons.

And a few years in the past, during this period of emission reduction measures and environmental protection supervision is also constantly introduced and strengthened. Recently, the State Council has issued the "13th Five-Year Plan" comprehensive energy-saving emission reduction program, "requirements by 2020, the national energy consumption per million Yuan than 2015 decreased by 15\%, total energy consumption control in 5 billion tons of standard coal within. National chemical oxygen demand, ammonia nitrogen, sulfur dioxide, nitrogen oxide emissions were lower than 2015, 10\%, $10 \%, 15 \%$ and $15 \%$. The total emissions of volatile organic compounds (VOCs) in the country fell by more than $10 \%$ from 2015, with the decline in total VOCs emissions being included in the planning target for the first time.

In order to control the haze, the Chinese government has made frequent policies and actions to devote a lot of manpower, material and financial resources, but with little success.

\section{THE FinANCIAL INSTITUTIONS IN DEVELOPED COUNTRIES IN THE MAIN WAY OF ENVIRONMENTAL PROTECTION}

In recent decades, the financial industry in the world, especially the developed countries, has played an important role in environmental protection. The main ways are:

\section{A. The Implementation of Green Credit}

Since the implementation of the Equator Principles, financial institutions and banks around the world have attached great importance to adopting green credit mechanisms to protect the environment and make rational use of environmental resources.

The so-called Equator Principles are the financial sector benchmarks established by major financial institutions in the 
world based on policies and guidelines of financial companies and the World Bank to determine the environmental and social risks in project financing. At present, more than $80 \%$ of the world's financial institutions have signed the "Equator Principles." The Equator Principles are widely used in international financing practices and develop into industry practices.

The most typical case is the American Bank of America has announced a total investment of up to 20 billion US dollars of green business development projects. Deutsche Bank, a policyoriented financial institution, has three roles in the field of environmental protection: one is an economic partner; two is the executive director of the federal government's environmental goals; thirty financiers of sustainable development projects, project clients Government, business, personal and so on. The terms of the loan are that the project must be able to improve the efficiency of energy consumption, use renewable energy, treat waste with a good economy, reduce waste water production, and discharge it.

\section{B. The Establishment of Environmental Funds}

In Western developed countries, the establishment of various environmental funds or foundations is an important environmental protection financial instruments. The sources of these funds include government budget allocations, taxes and fines from the production of polluting enterprises or environmentally harmful activities, as well as international rolls; funds are usually used for infrastructure construction and environmental accidents in environmental protection systems.

In 1988, the UK first introduced the first eco-fund, the MERLIN Eco-Fund, which combines investors' concerns about society and the environment with their financial investment objectives, and their investment objectives are more rational and overall Investment income in the long run but may be higher than the general investment funds.

\section{The Issuance of Municipal Bonds}

Developed countries have made decades of history by issuing municipal bonds to invest in urban environmental infrastructure. In the US water utility sector (including water supply, sewer network and treatment facilities construction and river dredging and other areas of governance, etc.), the annual constructive investment demand of about 230 billion US dollars, $85 \%$ of the investment from municipal bonds, government financial investment only accounting for $15 \%$. In Japan, municipal bonds are called local bonds, and their investment in urban sewage treatment facilities is $20 \%$ to $40 \%$ of the total investment in related facilities. European countries have a long history of municipal construction, financing practices are not the same, but most countries on the issuance of municipal bonds to adopt a more open policy, while the use of a variety of market-oriented approach to solve the municipal environmental public facilities financing.

\section{Emissions Trading}

Emission trading is in a region according to the environmental capacity of pollutants in the implementation of the total control under the premise of the Government through the market will be allocated to the emission rights of enterprises, reflecting a strong fairness and effectiveness, contribute to the economy and The coordinated development of the environment, its role is to limit the emissions of pollutants. This system originated in the United States in the late 1970s, but its application in the world is not very wide, only in the United States, Germany, Australia, Canada, and Singapore and so on.

\section{E. Environmental Pollution Liability Insurance (Green Insurance)}

Environmental pollution liability insurance refers to the insured person due to pollution of the environment should bear the responsibility of environmental compensation or governance responsibility for the responsibility of insurance. Environmental pollution liability insurance is a major part of ecological insurance, including the scope of environmental risk and cumulative environmental liability risk.

At present, the western developed countries common environmental pollution liability insurance are: general pollution liability insurance, security and compensation for environmental insurance, builder pollution liability insurance. Environmental pollution liability insurance was first introduced in the United States, and then the United Kingdom and Germany also began to implement. Britain to implement any risk-based, compulsory insurance supplemented by the system, the German compulsory insurance and government, financial institutions guarantee the system.

\section{The DeVElopment of ChinA's GREen FinANCE STAtUS QUO}

\section{A. Green Credit}

At present, Industrial Bank is China's first and only one "Equator Bank." Industrial Bank launched its first energy efficiency project financing product in China. In 2008, it became the first bank in China to adopt the Equator Principles. In 2014, it issued the green credit asset support securities in China and the first green financial debts in 2016.

In addition, the Construction Bank, the State Development Bank, the Industrial and Commercial Bank of China, the Bank of Beijing, the Bank of China and the Beibu Gulf Bank of Guangxi have also taken practical action on green credit. Although the above banks have carried out green credit exploration, but because of the lack of understanding of China's banking industry, both the impact of interest, green credit has not yet fully carried out.

And China's industrial banks to implement green credit there are many institutional and technical issues:

- (1) The ambiguity of policy standards. At present, the green credit business plan or stay in the policy level, there is no uniform standard, focusing on the internal control mechanism to promote the implementation of the bank, resulting in the bank's green credit line is the situation.

- (2) Green credit standards are comprehensive, principled, lack of specific green credit guidance catalog, environmental risk rating standards, etc., commercial banks difficult to develop relevant regulatory measures and internal implementation details, 
in the same legal system is difficult to develop And resume a set of political conditions to meet the specific situation and the actual institutions, methods and operational processes, greatly reducing the green credit class operation.

- (3)The status quo and characteristics of China's industrial structure have a restrictive effect on the construction of green credit mechanism. High pollution, high energy consumption industry as a result of some local policy protection, there are profitable, and some even short-term violence industry, it is difficult to significantly reduce the scale of credit.

- (4) Banking and environmental protection departments of the information communication mechanism is not perfect, did not really do data sharing

- (5) The lack of incentives to promote green credit incentives; green credit business innovation. For green credit, both at home and abroad are still in the exploratory stage, are looking for a bank, enterprises have the power of the financing model.

\section{B. The Environment Fund}

China's environmental industry fund is with the prosperity of the market economy gradually developed. In April 1993, the China Environmental Protection Foundation was established as the first non-profit private fund dedicated to environmental protection. August 23, 1996 Beijing Environmental Protection Foundation was established in 2002, Tsinghua Venture Capital as a fund manager, by the Hong Kong LESS company and other internationally renowned investment institutions funded the "China Environmental Industry Fund 2002" was formally established; August 2005 15, Jiangsu Province, the first environmental industry foundation - the new Asia Electronic Environment Industry Foundation was established, marking China's environmental protection investment fund to the direction of specialization.

From the investment point of view, most of China's environmental industry funds to invest in environmental protection industry, with the advantages of science and technology development of small and medium private enterprises. From the use of the current environmental industry funds, mainly used in the pollution control projects, the lack of environmental protection equipment, technology development and pollution-free technology projects investment.

July 20, 2007 set up the "China Green Carbon Fund" to become China's environmental industry fund pioneer, the fund is located under the China Green Foundation. The fund is cosponsored by the State Forestry Administration, China National Petroleum Corporation, China Greening Foundation, American Nature Conservation Association, Conservation International and Jiahan Company, and is open to domestic and foreign enterprises, organizations, groups and individuals. The fund is mainly used for: 1 , the implementation of the accumulation of carbon sink as the main purpose of the index of afforestation, forest management, biodiversity conservation and other related projects; Second, forestry carbon sink measurement and testing, carbon sink technical standards, Carbon sink management policy research and carbon sequestration related information release, etc.; Third, carry out forest and climate change forestry carbon sinks, biodiversity conservation and other related scientific knowledge popularization, publicity and training and other social welfare activities; Afforestation, research, publicity and overdue biodiversity conservation and other aspects of the outstanding contributions of enterprises, organizations, groups and individuals to commend and reward.

November 9, 2007, China's Clean Development Mechanism Fund Management Center was officially unveiled. In accordance with the regulations and management practices of the CDM, the Clean Development Mechanism Fund Management Center is subject to the supervision and guidance of the Audit Board and is responsible for the collection, collection, management and use of the Fund under the supervision of the Ministry of Finance. The use of the fund can be divided into four areas of business: capacity building and public awareness to improve business areas, mitigation of climate change business areas, adaptation to climate change business areas and services in the field of financial activities for the sustainable operation of the Fund.

At present, China's environmental industry funds work well.

\section{Green Insurance}

As early as the early 1990s, some cities in China to carry out environmental pollution liability insurance business, Dalian City, the earliest to carry out the business of the city and later, Shenyang, Changchun, Jilin and other cities have also carried out. However, environmental pollution liability insurance in China to carry out a small range, limited to a few cities, and in these cities in the scale of insurance is not large, only a few or more than 10 business insured, and insured into a downward trend, there are Of the city due to no business insurance, this business is now in a standstill. The reasons include: for the insurance company, the loss of pollution accidents can't be measured, insured risks and responsibilities are particularly large, so the enthusiasm is not high; and for enterprises, due to the lack of existing laws and regulations on the provisions of pollution compensation, Sewage companies even if the pollution caused by environmental losses, and rarely bear the liability for damages, when the main government or pay, so companies will not have the incentive to actively insured.

\section{Green Bonds}

In 2015, the first single Chinese green bonds listed on the London Stock Exchange, the People's Bank of China subsequently announced in the inter-bank bond market to launch green financial bonds, marking the official launch of China's green bond market, but also for financial institutions to expand the provision of green credit an important channel of funding. 2016 Industrial Bank landed the first domestic green financial bonds.

\section{The Prevention and Control of Haze Should PROMOTE THE DEVELOPMENT OF GREEN FINANCE}

\section{A. Financial Institutions Should Actively Fulfill Their Environmental Responsibilities}

The World Bank believes that corporate social responsibility is a collection of policies and practices that are relevant to key stakeholders, values, compliance and respect 
for people, communities and the environment[2]. It is a commitment that companies contribute to sustainable development by providing an overview of the quality of life of stakeholders. Financial institutions as a general sense of the enterprise must bear the direct social responsibility, especially environmental responsibility. At the same time, the financial institutions are a business risk, to provide funds for special enterprises in China's economic life occupies an important position.

It is worth mentioning is that commercial banks, commercial financing accounted for more than $80 \%$ of corporate finance, other organizations to guide the community to encourage and restrict their social responsibility to fulfill the special function. Commercial banks in the process of credit audit and decision-making should be the development of circular economy, the protection of the natural environment and the maintenance of ecological balance as an important reference for the issuance of loans. At the same time, the customer's environmental risk into the credit investment assessment, and gradually promote the environmental credit risk assessment system, in the accounting statements to fully reflect the contents of the environmental report. In addition, it should be actively involved in environmental investment, whether it is investment in a favorable environment for the environment and the benefits of investment projects can be shared to the interests.

\section{B. To Strengthen the System Construction, Construction and Development of Green Financial Incentive Mechanism}

The development of green finance should also build an incentive mechanism at the institutional level. From the government point of view, we should first develop relevant regulations, standards and preferential policies to encourage financial institutions to improve their environmental responsibility and enhance the enthusiasm of the opportunity to capture the environment. Second, we should formulate relevant laws, regulations and policies to promote the rise and development of green financial products suitable for China's national conditions.

As a financial institution, it should also formulate policies related to green finance and construct appropriate management institutions and systems, action plans and supervision procedures, and regularly publish environmental assessment reports to the outside world.

\section{To Nurture and Improve the Social Development of Green Financial Assessment Mechanism}

China has introduced some green credit policies and rules, but the principle of equator has not yet fully promoted in China, at present only Industrial Bank is "Equator Bank"; In addition, China's commercial banks green credit standards are also developed by the banks themselves, to be fragmented.

Guo Lian believes that the introduction of green financial community assessment mechanism is to be independent of the independent social institutions as a third party on the use of green financial regulations, regulations and guidelines for independent review and assessment of its climate change and environmental protection issues And the ability to serve the financial market, according to the green finance climate and environmental integration to provide independent second opinion. This institution is not necessarily an assessment or a research institution. There are certain success stories and experiences in this area, such as the Green Claims Initiative (GBPs), the Climate Bond Initiative CBI, the Environmental Responsibility Economic Alliance (CERES), the VIGEO Rating Company's Environment, Social Responsibility and Governance (ESR) Norway DNV's second opinion.[1]

\section{To Play The Guiding Role of the Government}

At present, China's haze management work stagnant, local government protectionism also has a certain impact. At present, China's high-polluting enterprises have living space, and even high profits, is the leading enterprises, large profits and taxes, local governments for local economic considerations, there is pressure to the commercial banks, which to some extent Obstruct haze management and green finance promotion. In the process of managing haze and developing green finance, the government departments should face up to the problem of "offside" and "absence". China's market economy is booming, the market regulation, and the decision to do things by the market to do. The government needs to do is to combine the green economy and sustainable development of the relevant indicators to assess the local performance, to promote the local government to actively cooperate with the development of green finance.

\section{CONCLUSION}

In short, the prevention and control of haze to give full play to the role of green finance. Capital is the enterprise's blood, is the basis for the survival and development of enterprises, the current financing of Chinese enterprises mainly from the financial industry. Financial means a variety of direct cut in the lifeblood of corporate finance, green finance in environmental governance promising, China should pay attention to the development of green finance.

\section{REFERENCES}

[1] Guo Lian. Green economy in the development of government and market [N] .21 century economic report .2014-01-06 (1)

[2] Shao Lun Cai, “Analysis of Finance and Environmental Protection”, Advanced Materials Research, 2012, pp. 789-792,J. Clerk Maxwell, A Treatise on Electricity and Magnetism, 3rd ed., vol. 2. Oxford: Clarendon, 1892, pp.68-73.

[3] Ma Jun. On the construction of China's green financial system [J]. Financial Forum .2015 (5), pp.18-21

[4] Southwest University of Finance and Economics Development Research Institute, Ministry of Environmental Protection Environmental and Economic Policy Research Center Group of green finance and sustainable development [J]. Financial Forum .2015 (10), pp.30-40

[5] Yuan Zhihui. Green bonds are haze days of financial "purifier" [J]. China Economic Weekly .2016 (1), pp.78

[6] Deng Xiang. Review of Green Finance Research [J]. Journal of Zhongnan University of Economics and Law .2012 (6), pp.67-71

[7] Guo Lian. Green economy in the development of government and market [N] .21 century economic report .2014-01-06 (1)

[8] Wang Tian Tian. Improve the green financial system to improve the haze environment [N]. China Economic Times .2015-12-03 (2) Guo Lian, "Low-carbon economy and environmental finance: theory and practice”.[978-7-5049-5785-6]Beijing. China Financial Publishing House .2011, pp.29-34,83-129. 